\title{
Okresní školní inspektor a počátky státního dohledu nad obecným školstvím v Čechách v letech 1869-1873
}

\author{
Martin Klečacký ${ }^{a}$ \\ a Masarykův ústav a Archiv AV ČR, v. v. i. \\ klecacky@mua.cas.cz \\ Received 14 June 2021 \\ Accepted 9 November 2021 \\ Available online 31 December 2021
}

DOI 10.15240/tul/006/2021-2-003

Abstract District School Inspector and the Beginning of State Supervision over General Education System in Bohemia 1869-1873

The paper deals with the adoption of School Supervision Act from 1869 in Bohemia, taking into account both Czech and German speaking milieus. Using the example of appointment of District School Inspectors and looking into their activities, it analyses the system deficiencies and complications that the state authorities had to cope with in the first years after adoption and that, eventually, led into an amendment of the aforementioned act four years later. Apart from the inadequate organisational background and salary conditions of district inspectors, the paper points out the financial requirements that the school reform brought about and that had to be covered mostly by local municipalities. This fact significantly contributed to a generally passive or even negative attitude held by autonomous corporations as for the new school legislature implementation, which was enhanced by oppositional stance of Czech political representation.

Keywords school inspection, Austria, school administration, Bohemia, 1869-1918

\section{Úvod}

Dne 25. října 1867 předložil poslanec říšské rady Eduard Herbst plénu sněmovny návrh zákona na laicizaci dohledu nad rakouským školstvím. Již samotná osobnost překladatele, jednoho z vůdců liberální strany v Rakousku a budoucího ministra, jasně ukazovala na význam, jaký mělo zřízení moderní školní inspekce založené na pedagogicko-didaktických principech a podléhající jednotnému řízení pro tehdejší liberální politiky. Během následujícího legislativního procesu bylo 
nutné zvážit a vyrovnat jak zájmy státu, jehož cílem byla výchova a vzdělání svých občanů podle liberálních zásad, tak i církve, která se snažila udržet spojení mezi vzděláním a mravní, resp. náboženskou výchovou, a v neposlední řadě rodičů dětí. Ti zde vystupovali nejen jako zástupci svých ratolestí, pro něž bylo klíčové zajistit svým dětem základy pro budoucí samostatné uplatnění a profesní existenci, ale i jako voliči a daňoví poplatníci, z jejichž peněz se celá školská soustava financovala (Šafránek, 1918). Nové školské zákony měly definitivně ukončit období, kdy rakouské školství stálo pod kontrolou církevních úřadů, kdy na lokální úrovni učitelé stále podléhali dozoru okresního školdozorce, kterým byl vikáŕ římskokatolické církve, a kdy církevní hodnostáři mohli ovlivnit nejen složení pedagogického sboru, ale i strukturu a obsah výuky.

Ve své studii se zaměřím na úspěšnost prosazení legislativních opatření v praxi s ohledem na politické, ale i správní poměry v Čechách přelomu 60. a 70. let 19. století. Zajímat mě bude především proces jmenování okresních školních inspektorů, kteří pro mě představují klíčového aktéra zestátnění školního dozoru. $\mathrm{Z}$ tohoto důvodu je článek založen $\mathrm{v}$ první řadě na analýze spisového materiálu z provenience dvou zemských institucí se vztahem ke školské správě - českého místodržitelství a zemské školní rady. Právě perspektiva státu a jeho úředníků je podle mého názoru chybějící komponentou ve výzkumu školské soustavy 19. století, založeného dosud zejména na pramenech osobní povahy, archivních fondech z činnosti samosprávných úřadů, případně tisku a dobových odborných periodik. ${ }^{1}$ Současně fondy

1 K výzkumu školské soustavy a vývoje školské správy (včetně organizace školního dozoru) srov. zejména BARTOŠOVÁ, Jana, ŠIMEK, Jan \& ŠUSTOVÁ, Magdaléna, 2019. Od školdozorce k inspektorovi. Historie školní inspekce. Praha: Česká školní inspekce ve spolupráci s Národním pedagogickým muzeem a knihovnou J. A. Komenského. ISBN 978-80-86935-46-1; dále VOŠAHLÍKOVÁ, Pavla, 2016. Rákoska v dílně lidskosti. Česká škola v 19. století očima účastnikư. Praha: Academia. ISBN 978-80-200-2533-3; HLAVAČKA, Milan, 2006. Zlatý věk české samosprávy. Samospráva a její vliv na hospodářrký, sociální a intelektuální rozvoj Čech 1862-1913. Praha: Libri. ISBN 80-7277-297-X, s. 90-106. Z novější literatury se postavení školy, učitelů i školních dozorců věnuje na př́ikladu Moravy a Slezska: CIBULKA, 
zemské instance představují často jediný ucelený zdroj úřední povahy, který spolehlivě zachycuje proces výstavby státní školní inspekce, což je způsobeno špatnou úrovní dochování a neúplnostílokálních archivních pramenů. Chování státních úřadů budu sledovat v celkovém kontextu tzv. dvoukolejné veřejné správy, jak se v Rakousku etablovala nejpozději od počátku 60. let 19. století. Pozornost proto zaměřím také na interakci zestátněných školních úřadů s obecní či okresní samosprávou.

Původní Herbstova předloha prošla v říšské radě bouřlivými debatami, a to především v její horní - panské - komoře, kde byly tradičně zastoupeny především konzervativní elementy v podobně církevních hodnostářů a pozemkové aristokracie. Její konečné prosazení bylo možné v důsledku silného poklesu panovníkovy autority po prohrané válce s Pruskem v roce 1866 a vynuceném vyrovnání s Uherskem, které umožnily liberálním politikům postavit rakouský ústavní a správní systém na moderních liberálních principech. Jeden z těch nejdůležitějších představovalo právě jasně vymezení sfér vlivu státu a církve v oblasti školství (Engelbrecht, 1982, s. 111-116; Strakosch-Grassmann, 1905, s. 256-258). Zákon o organizaci obecného školství č. 48 ř. z. z 25. května 1868, jeden z tzv. májových zákonů, nově upravujících vztah státu a církve, ve svých ustanoveních omezoval vliv církevních hodnostářů pouze na výuku náboženství. Ostatní předměty byly svěřeny učitelům bez ohledu na jejich náboženskou příslušnost a učebnílátka nově neměla podléhat žádnému dohledu ze strany církevní autority. S tím velmi úzce souvisela i otázka kontroly provádění a dodržování školských zákonů. Tzv. školní dohlídku nemohli již nadále z principu vykonávat místní vikáři z pověření biskupa nebo dokonce ordináři osobně, nový zákon proto zaváděl kompromisní řešenív podobě školních rad na místní, okresní a zemské úrovni, ve kterých měli zasednout zástupci státu, církví, příp. dalších náboženských společností, samosprávy zastupující voliče a daňové poplatníky a také samotných učitelů. Rady sice fungovaly jako kolektivní orgány, jejich předsedou na okresní i zemské

Pavel, KLADIWA, Pavel, POKLUDOVÁ, Andrea, POPELKA, Petr \& ŘEPA, Milan, 2021. Čas změny. Moravský a slezský venkov od zrušení poddanství po Velkou válku. Praha: Masarykův ústav a Archiv AV ČR, v. v. i. ISBN 978-80-7599-225-3, s. 143-180. 
úrovni byl však státní úředník s výkonnými orgány - školními inspektory - také jen zaměstnanci státu (Engelbrecht, 1982, s. 88-91; Šafránek, 1918, s. 305-310).

\section{Zavedení institutu okresního školního inspektora v Čechách}

Konkrétní podoba, složení a fungování školních rad však byla ponechána zemskému zákonodárství, což se ukázalo jako kámen úrazu. Zemský sněm v Tyrolsku se např́iklad usnesl na takových předlohách, které byly v přímém rozporu s intencí ŕíšského rámcového zákona. Liberální většiny na Moravě, Slezsku, Horních či Dolních Rakousích naopak církevní zástupce bud' téměř ze školní správy vyloučily, nebo jim přisoudily jen zcela formální roli. Žádný z těchto zákonů proto nezískal panovnické schválení a provádění školských reforem tak ve většině rakouských korunních zemí až do roku 1870 probíhalo provizorně na základě ministerských instrukcí a vyhlášek. Jedním z mála sněmů, který se dokázal usnést na znění zákona respektujícího podmínky říšské normy, byl český zemský sněm ovládanýv té době německojazyčnými liberály a poslanci za ústavověrný velkostatek (Strakosch-Grassmann, 1905, s. 263; Kolmer, 1902, s. 378-379, 400-401). Zemský zákon o dohlídce ke školám z 8 . února 1869 sice částečně respektoval specifické národnostní poměry v Čechách, když ve smíšených okresech zaváděl oddělené školní rady pro školy s českým či německým vyučovacím jazykem, po svém vyhlášení se však potkal s takovým odporem, že jeho ustanovení mohla být realizována jen se zpožděním, improvizovaně, zřízené školní rady fungovaly s vypětím všech sil, v omezeném složení a o řádném plnění jejich povinností nelze vůbec mluvit (Tobolka, 1913, s. 246-257).

Vůbec největším problémem se v českých podmínkách stalo jmenování okresních školních inspektorů, zodpovědných za dohled nad obecnými a měštanskými školami v okrese. ${ }^{2}$ U okresních inspek-

2 Obecné a měštanské školy podléhaly bezprostřední a pravidelné kontrole okresních školních inspektorů a jen namátkové a nahodilé kontrole vybraných zemských školních inspektorů, naopak pro střední školy a učitelské ústavy byla kompetentní jen zemská školní rada a jejich kontrolu prováděli proto výlučně zemští školní inspektoři. 
torů zákon předpokládal, že vyjdou z místních školských expertů, zkušených učitelů a ředitelů obecných škol. Tato představa se však ukázala být zcela iluzorní - tím spíše, když zemští zákonodárci do textu vpravili § $28,{ }^{3}$ který zřizovatelům škol dával právo, aby odmítli „svého“ učitele propůjčit státní inspekci. ${ }^{4}$ Úřad okresních inspektorů byl totiž z úsporných důvodů zřízen jen jako vedlejší činnost, kterou jmenovaní učitelé (a nejen ti) měli vykonávat ve volných chvílích bez újmy na svém stávajícím povolání (Macková, 2011, s. 8-10). Zejména v prvních měsících a letech následujících po prosazení takto přelomových změn v organizaci školství šlo o naivní předpoklad. Právě na odporu obcí, které neměly zájem ztrácet své schopné a zkušené učitele, a na nedostatečném organizačním zázemí a zajištění ztroskotala pưvodní koncepce a zemská školní rada musela přistoupit k permanentní improvizaci. ${ }^{5}$

Okresní školní inspektor měl působit jako odborný referent okresní školní rady, kdy by zastával roli pravé ruky okresního hejtmana pro školské otázky. Zatímco hejtman se jako právník měl zabývat hlavně administrativně finančními záležitostmi, u inspektora se čekalo, že se bude věnovat personáliím podřízených učitelů a také odborně pedagogickým otázkám. Vedle př́ípravy podkladů pro rozhodování okresní školní rady a následně provádění jejích usnesení v praxi musel minimálně několikrát ročně navštívit všechny podřízené školy a osobně se přesvědčit o stavu výuky. Ve skutečnosti však nežrídka celá tíha školní administrativy ležela na inspektorovi, pro okresního hejtmana školní rady představovaly novou a nepř́liš vítanou agendu, pro kterou neměl ani čas, ani pracovní sílu.

Jen těžce proveditelná byla $\mathrm{v}$ praxi rovněž povinnost zemské školní rady navrhnout ke jmenování pro každý okres tři nejvhodnější

3 Srov. zákon č. 26 z. z. ze dne 8. 2. 1869, jenž se týče dohlídky ku školám, § 28. Zemský zákoník království českého, 1869, částka VII, s. 38.

4 Výnos zemské školní rady v Čechách ze dne 2. 12. 1869, č. j. 3509/LSR. Fond Zemská školní rada Praha (ZŠR), karton 15, signatura I/10/4. Národní archiv (NA).

5 Zpráva okresní školní rady v Rumburku na zemskou školní radu v Čechách ze dne 3. 2.1870, zpráva zemské školní rady v Čechách ministru kultu a vyučování ze dne 2. 3. 1870, č. j. 765/LSR. Fond ZŠR, karton 16, signatura I/10/4. NA. 
kandidáty, z nichž by ministr kultu a vyučování jednoho vybral. Jednotlivé zprávy opakovaně uváděly, že v některých okresech bylo štěstí, pokud se podařilo sehnat alespoň jednoho vhodného kandidáta, který byl ochoten funkci přijmout. $V$ celé řadě míst se nenašel vůbec nikdo. Kromě odporu obcí, politické agitace ze strany české státoprávní opozice neměli učitelé zájem o administrativně náročnou a špatně placenou pozici. Na druhou stranu ani zemská školní rada nevybrala každého. Vedle pedagogických zkušeností hrál dưležitou roli i politický profil kandidáta. Ti, kteří se „kompromitovali“ odmítavým postojem proti školským zákonům, rakousko-uherskému vyrovnání, či volili během zemských voleb opoziční kandidáty, byli na základě posudku okresního hejtmana automaticky vyloučeni. ${ }^{6}$

Rezervoár možných kandidátů z učitelského povolání se tím velmi omezil a okresní hejtman - navzdory dưraznému doporučení zemské školní rady - často navrhoval raději místního děkana nebo některého $\mathrm{z}$ okolních farářů, u kterého předpokládal zkušenost s vedením mládeže z předchozích dob a rezervovaný postoj k nacionální agitaci. $^{7} \mathrm{Z}$ celkem 79 osobností, které zemská školní rada na jaře 1869 získala v podobě návrhů šéfů okresních hejtmanství (a budoucích předsedů okresních školních rad) jich 29, tj. 36 \%, znělo na jméno místního duchovního. U těch farářư, kteří současně zastávali funkci biskupského vikáře, by to $\mathrm{v}$ důsledku znamenalo, že setrvají ve své roli okresního školdozorce i po přijetí liberálních školských zákonů. Dalších 22, tj. 28 \%, navržených jmen byli většinou ředitelé a učitelé hlavních (pozdějších měštanských) škol, 17 kandidátů, tj. $21 \%$, představovali profesoři a ředitelé střredních škol, a to především v okresech, kde fungovala nějaká reálka nebo gymnázium. A v devíti případech (11\%) bezradný

6 Přednesení referenta J. V. Grohmanna ve schůzích zemské školní rady, 21., 23., 25. a 28. 8. 1869, č. j. 1579/LSR. fond ZŠR, karton 16, signatura I/10/4. NA.

7 Telegram PM na dohlédací okresní hejtmany v Čechách ze dne 30. 6. 1869, č. j. 2099. Fond Prezidium místodržitelství Praha (PM), karton 806, signatura 6/5/31. NA. 
okresní hejtman dokonce navrhl za inspektora někoho zcela mimo školskou soustavu (např. lékárníka, lékaře nebo místního advokáta). ${ }^{8}$

Zemská školní rada však nebyla návrhy okresní instance nikterak vázaná. Ostatně u některých referentů, kteří vedli tato jednání týkající se konstituování nové školské správy a jmenování inspektorů, lze předpokládat silné sympatie s politickým programem liberální strany. Za klíčového muže a hybatele školské reformy můžeme považovat místodržitelského radu Johanna Virgila Grohmanna, kterýv 60. letech zasedal v českém zemském sněmu a tato jeho veřejná angažovanost jej během vlády konzervativního kabinetu Richarda Belcrediho stála dokonce místo ředitele litoměřické reálky. Nicméně po liberálním obratu v rakouské politice se v roce 1869 stal referentem zemské školní rady (navzdory absenci právnického vzdělání) a z této pozice vlivným propagátorem školské reformy v Čechách (Klečacký et al., 2020, s. 204).

Během projednání konečné nominace se Grohmannovi podařilo snížit počet navržených duchovních z 29 na 14, naopak počet středoškolských učitelů vybraných pro funkci okresního školního inspektora narostl ze 17 na 42, což představovalo 44 \% všech 95 jmen odeslaných na ministerstvo kultu a vyučování do Vídně. Z pohledu státu byli profesoři středních škol ideálními kandidáty, protože byli na rozdíl od učitelů obecných škol v přímém zaměstnaneckém poměru ke státu, nehrozilo proto, že by úřad demonstrativně odmítli, nebo jej sabotovali. Z pedagogického pohledu však již byla situace komplikovanější. Od okresního školního inspektora se očekávalo, že bude v kontaktu výhradně s dětmi a učiteli obecných a měštanských škol, tyto zkušenosti však středoškolští profesoři většinou postrádali a navíc byli vzhledem ke své aprobaci zaměřeni vždy jen na některé předměty (C. k. okresní inspektoři škol, 1869, s. 345-346). ${ }^{9}$

8 Přehled sestaven na základě návrhů jednotlivých okresních hejtmanství in: Vorschlag für die Besetzung der Bezirksschulinspektoren im Königreiche Böhmen, č. j. 2297 pres. Fond ZŠR, karton 15, signatura I/10/4. NA. Zbývající dvě osobnosti se mi nepodařilo profesně zařadit.

9 Výnos ministra kultu a vyučování ze dne 21. 9. 1871, č. j. 11305/LSR. Fond ZŠR, karton 1 , signatura I/1/23. NA. 


\section{Problémy zákonné úpravy $\mathbf{v}$ praxi}

Palčivým problémem se stala trvalá nepřítomnost inspektora v sídle okresu. Jelikož profesoři představovali pro vládu ideální zdroj kandidátů, kteří nemohou odmítnout, nebyly výjimečné situace, kdy např. z pražských gymnázií a reálek se každý týden rozjížděli inspektoři do Poděbrad, Slaného, Hořovic či Loun, podobně zásobovaly okolní okresy i střední školy z Písku, Tábora či Plzně. Takový stav, kdy profesor několik dnů v týdnu učil na svém domovském ústavu, dalších několik dnů bud' zasedal v okresní školní radě, nebo jezdil po venkovských školách po inspekci, byl dlouhodobě neudržitelný (Jessen, 1870, s. 801-802). A to jak pro školní úřady, tak i pro inspektora samotného. $V$ roce 1870 proto následovala vlna rezignací z důvodu nedostatečného cestovního paušálu, rodinných či zdravotních problémů. Např. vysokomýtský inspektor Jan Smita se po smrti své manželky staral sám o dvě děti a cesty z Prahy do Mýta tak pro něj nepřipadaly více v úvahu, kromě toho, jak sám doznal, byl „dosud odborným učitelem na střední škole a o obecném školství mnoho nevím, musel bych se proto ještě s mnohým seznámit, na což v nynějších poměrech nemám sílu“ ${ }^{10}$ Inspektor pro okres Blatná Václav Babánek pravidelně cestoval ze svého domovského gymnázia v Písku, po roce však rezignoval, když mu „trmácení cestou do Blatné zhoršilo žaludeční katar natolik, že se nemohl ani zúčastnit ustavující schůze okresní školní rady“." ${ }^{11}$

Jenomže vláda neměla kromě středoškolských kantorů nikoho jiného, na koho by bylo možné se spolehnout. Z 22 jmenovaných inspektorů vyšlých z řad učitelů obecných škol jich deset nezískalo souhlas příslušné obecní samosprávy, která je platila a neměla důvod své nejlepší učitele půjčovat zadarmo eráru. A to se netýkalo jen českých obcí, u kterých se podobný postoj mohl svést na pasivní rezistenci a opozici vůči centralistické vládě, své učitele odmítly poskytnout např́klad Kadaň, Chomutov, Hodkovice nad Mohelkou, Mariánské Lázně, pak

10 Žádost J. Smity zemské školní radě v Čechách ze dne 18. 11. 1870, č. j. 8556/LSR. Fond ZŠR, Karton 16, signatura I/10/4. NA.

11 Žádost V. Babánka zemské školní radě v Čechách ze dne 28.11. 1869, č. j. 3454/LSR. Fond ZŠR, karton 15, signatura I/10/4. NA. 
také Mladá Boleslav, Kostelec nad Orlicí či Sušice. ${ }^{12} \mathrm{~V}$ posledním případě byl vybraný učitel zároveň dočasným správcem školy za duševně nepříčetného ředitele a jeho pověření okresní inspekcí z pohledu obce ohrožovalo samotný chod školy. ${ }^{13}$ Přes četné intervence, přímluvy a domluvy okresních hejtmanů setrvávaly obecní výbory na svém negativním stanovisku, ministerstvo nakonec tedy muselo dočasně ustoupit a hledat nové kandidáty. ${ }^{14}$ To se ne vždy podařilo a školy v okrese Planá tak zůstaly od roku 1869 další tři roky bez inspektora, ${ }^{15}$ stejně tak iluzorní byla inspekce v Klatovech, kde se výběr nového inspektora táhl více než rok. ${ }^{16}$

Ideální představa ministerstva, že inspektor bude rádcem starších učitelů, pomocníkem a průvodcem mladé učitelské generace, že bude recipovat nejnovější poznatky pedagogiky a didaktiky a pomáhat tím osvětě a výchově nové generace rakouských občanů, se střetávala s realitou českých poměrů. V záŕí 1871 vydal ministr kultu a vyučování Josef Jireček výnos, kterým de facto zakázal další jmenování středoškolských profesorů do inspektorských funkcí. Bez ohledu na vyšší finanční náklady spojené např́klad se zajištěním suplujícího učitele se měla zemská školní rada zasadit o to, aby se do této důležité funkce dostali výhradně učitelé z místního okresu či nejbližšího okolí. ${ }^{17}$ Již učiněné návrhy tak putovaly z Vídně zpět do Prahy a v celé řadě míst se okresní hejtman znovu a marně pokoušel najít někoho vhodného z místních kantorů, kteří by z odborného i politického hlediska dostáli kladeným

12 Výnos zemské školní rady v Čechách všem okresním hejtmanům ze dne 9.12.1869, č. j. 3814/LSR. Fond ZŠR, karton 15, signatura I/10/4. NA.

13 Zpráva městské rady v Sušici okresnímu hejtmanu v Sušici ze dne 24. 11. 1869, č. j. 3422/LSR. Fond ZŠR, karton 15, signatura I/10/4. NA.

14 Zpráva okresního hejtmana v Liberci zemské školní radě v Čechách ze dne 6.12.1869, č. j. 3724/LSR. Fond ZŠR, karton 15, signatura I/10/4. NA.

15 Výnos zemské školní rady okresní školní radě v Plané ze dne 26. 7. 1870, č. j. 4375/ /LSR. Fond ZŠR, karton 16, signatura I/10/4. NA.

16 Zpráva zemské školní rady ministerstvu kultu a vyučování ze dne 12. 7. 1871, č. j. 2372/LSR. Fond ZŠR, karton 16, signatura I/10/4. NA.

17 Výnos ministra kultu a vyučování zemské školní radě v Čechách ze dne 21. 9. 1871, č. j. 11305/LSR. Fond ZŠR, karton 1, signatura I/1/23. NA. 
nárokům, kteří by o tuto práci měli zájem a jimž by jejich zaměstnavatel udělil nutný souhlas. Poslední podmínku nakonec částečně vyřešila změna zákona o zřizování a vydržování obecných škol z února 1870. Krátké ustanovení o tom, že školy napříště nevydržují jednotlivé obce, ale školní okres, do jehož okresního školního fondu obce přispívají alikvotní částkou, zajistilo, že do budoucna souhlas učitelům s přijetím inspektorské funkce udělovala okresní školní rada, nikoliv jednotlivé obecní výbory. ${ }^{18}$

Jako poražený $\mathrm{z}$ tohoto procesu vyšly právě obce, především ty bohatší, progresivnější a řádně spravované, protože zmíněnou legislativní změnou přišly o své školy a školní budovy. Jejím novým vlastníkem byl okresní školní fond a do něj musely obce platit bez ohledu na to, zda své školy v předchozích letech nově postavily, renovovaly či nově vybavily. Pokud tyto obce spoléhaly na to, že si těmito investicemi na léta dopředu zajistily řádně fungující místní školství, o to trpčí muselo být po roce 1870 zjištění, že budou platit znovu a dál. Nově vlastně solidárně přispívaly na vydržování škol v sousedních obcích, kde samospráva v předcházejících letech nechala školy chátrat a neutratila nic ani za jejich vybavení. Navíc z pohledu obecní samosprávy nad svými prŕíspěvky neměly ani patřičnou kontrolu, ta totiž přecházela do rukou okresní školní rady, v níž zástupci samosprávy tvořili jen menšinu. ${ }^{19}$

Právě finanční otázka stála za odporem proti školským zákonům nejen ze strany samosprávy, ale i daňových poplatníků. Z hlediska běžného občana stát novými zemskými zákony sice ukládal povinnost platit školské přirážky do okresního školního fondu, ale nenabízel žádné zlepšení stávajících poměrů. Ve škole i nadále zůstávali starší a vysloužilí učitelé, kteří sice nevyhovovali novým nárokům kladeným na učitelskou profesi, ale nedosáhli ještě věku na odchod do penze. V průběhu roku 1870 došlo k postupné klasifikaci škol a jejich rozřazení podle

18 Srov. zákon č. 22 z. z. ze dne 19. 2.1870, kterým se upravuje zřizování, vydržování a navštěvování veřejných škol národních, §§ 37-38. Zemskýzákonik královstvíčeského, 1870, částka VII, s. 79-80.

19 Zpráva českého místodržitele ministru kultu a vyučování ze dne 24. 12. 1870, č. j. 4444. Fond PM, karton 806, signatura 6/5/31. NA. 
drahotních poměrů, což přímo ovlivňovalo výšku učitelských platů. Jejich nezrrídka prrímo skokový nárůst vyvolával především ve venkovských obcích rozhořčení. Jak referoval místodržitelský rada v Táboře, šírílo se okresem přesvědčení, že „za to, co vědí, byli bývali zaplacení dost“ “ ${ }^{20}$ Obecný učitel si polepšil na místo původních $500 \mathrm{zl}$. na 1100 zl. ročně, získal jistotu pravidelné výplaty z okresní školní pokladny, nárok na penzi a zabezpečení i svých rodinných příslušníků (Vošahlíková, 2016, s. 138-145).

Vedle povinnosti školských přirážek se s nepochopením setkalo i ustanovení o prodloužení povinné školní docházky do ukončeného 14 . roku věku. Právě tato změna zasáhla především méně majetné vrstvy. V řemeslnických a dělnických rodinách bylo běžné, že synové ve dvanácti letech odcházeli na učení řemeslu, př́ípadně že se začali podílet na výživě rodiny, v každém případě již nechodili do školy a rodina nemusela více platit školné. Další dva roky ve škole se při zachování stejného učebního plánu zdály být ztraceným časem, navíc když pro tyto děti v přeplněných třídách často nebylo ani místo. ${ }^{21}$

Nové školské zákony vyvolávaly negativní reakce či přímo odmítání na celém území Čech, v německých okresech byl však jejich dopad částečně mírněn liberální orientací tamějších samospráv, které byly ochotné navzdory tíživým finančním břemenům spolupůsobit při reformě školského systému. Tuto vstřícnost bychom v českojazyčných okresech hledali mnohem obtížněji. Povinnosti, které s sebou školské zákony přinášely, se setkávaly s o to důslednějším odmítáním, protože přicházely od centralistické vlády, byly přijaty ve Vídni ústředním parlamentem, a nikoliv zemským sněmem, a protože tvořily součást liberálního programu, který stál $\mathrm{v}$ přímé opozici $\mathrm{k}$ federalizačním snahám české politiky i šlechty (Srb, 1899, s. 243). Národní strana, tzv. staročeši, se právě v případě školských zákonů ocitla v nepř́ijemném sevření, kdy byla nucena bojovat proti zákonům ne pro jejich obsah, ale jen pro

20 Zpráva místodržitelského radyv Táboře prezidiu místodržitelství ze dne 8.11.1870, č. j. 4771. Fond PM, karton 806, signatura 6/5/31. NA.

21 Zpráva českého místodržitele ministru kultu a vyučování ze dne 24. 12. 1870, č. j. 4444. Fond PM, karton 806, signatura 6/5/31. NA. 
jejich vnější formu, způsob přijetí a proto, že nevyhovovaly spojencům ze strany konzervativního velkostatku. Tato perspektiva se však jen těžko vysvětlovala samotným učitelům, pro které představovaly „rakušácké“ zákony ohromné zlepšení jejich materiálního postavení i společenského statusu.

Rozhodně tak nelze paušálně tvrdit, že se školské zákony v Čechách setkaly na místní úrovni s rozhodnou opozicí na české straně a nadšeným přijetím v německých okresech. Realita byla mnohem pestřejší a proces implementace školských norem vyžadoval zapojení celé řady místních aktérů, z nichž zcela klíčovou roli hráli okresní školní inspektor, okresní hejtman jako předseda okresní školní rady, jednotliví obecní starostové a ředitelé a správci místních škol. Když ve své zprávě okresní školní inspektor v Domažlicích popisoval výsledek své inspekční cesty, mohl zcela jednoznačně potvrdit, že odpor učitelů proti školským zákonům - politicky motivovaný Národní stranou - byl zlomen hned v zárodku. Krátce poté, co se okresnímu hejtmanovi Antonu Füllekymu podařilo přesvědčit místní starosty ke zřízení místních školních rad a co se ustavila i okresní školní rada, sestavila rozpočet a vypsala školní přirážky, začala učitelưm chodit pravidelná měsíční gáže. Učitelé se tím emancipovali nejen od místních farárưu, ale i starostů a stali se z nich veřejní činitelé s postavením státního úředníka, stálým příjmem, sociálním zabezpečením i volebním právem. ${ }^{22}$ Podobně úspěšný byl ve svém okrese i táborský místodržitelský rada Jan Bradáč, kterému se dokonce podařilo přesvědčit starosty k automatickému paušalování školních dávek, čímž ušetřil za jejich administraci. ${ }^{23}$ Okresní hejtman ve Vrchlabí Julius Kromer a tamní okresní školní inspektor Wenzel Weber vytvořili natolik sehraný tandem, že v okrese během tří let vyrostlo šest nových školních budov. Takový rozmach školství byl možný jen rychlým a efektivním provedením všech nových zákonných opatření, na kterém měl

22 Zpráva okresní školní rady v Domažlicích zemské školní radě v Čechách, [únor 1871], č. j. 2757/LSR. Fond ZŠR, karton 16, signatura I/10/4. NA.

23 Zpráva zemské školní rady v Čechách ministru kultu a vyučování ze dne 21.1.1874, č. j. 15308/LSR. Fond ZŠR, karton 17, signatura I/10/4. NA. 
školní inspektor klíčový podíl, přestože šlo o katolického duchovního, místního děkana a bývalého školdozorce. ${ }^{24}$

Okresní školní inspektor v Horšovském Týně, farář Josef Maras měl být údajně autorem kritického článku odsuzujícího dopady školské reformy. Když tento případ vyšel najevo, ukázalo se během následného vyšetřování, že farář sice satirický článek sepsal, ovšem jen na přání biskupské konzistoře a s jeho uveřejněním nesouhlasil (k postoji českého episkopátu ke školským reformám srov. Balík et al., 2015, s. 121-124). Okresní hejtman duchovního bez váhání označil za zastánce školských zákonů a zemská školní rada se nakonec usnesla, že vyšetřování zastaví. Sám referent projevil pochopení a lítost nad dvojím postavením okresního školního inspektora, který je sice přesvědčen o správnosti školské reformy, ovšem jeho postavení katolického duchovního jej nutí k velké rezervě v jeho postojích. ${ }^{25}$

Do podobně problematické pozice se dostávali i místní samosprávní činitelé. Starostu v Čáslavi Rudolfa Jablonského navrhl místní okresní hejtman k vyznamenání rytířským kř́ǐzem Řádu Františka Josefa pro jeho vstřícný postoj k vládním reformám, mimo jiné ke školským zákonům. Jablonský, který sice jako poslanec českého zemského sněmu provozoval pasivní rezistenci, se ve svém městě choval zcela opačně. Díky jeho podpoře se podařilo v místě ustavit školní radu, jeho vliv hejtman ocenil i při prosazení výstavby nové školní budovy v okresním městě. ${ }^{26}$ Podobně si počínal i okresní starosta v Německém Brodě Eduard Brzorád (otec pozdějšího stejnojmenného mladočeského politika). Společně ještě s jedním členem okresního výboru se postavil novinovým výzvám k odepření voleb do okresní školní rady a obratným vyjednáváním je dokázal v okresním zastupitelstvu prosadit s tím, že se

24 Zpráva zemské školní rady v Čechách ministru kultu a vyučování ze dne 21.1.1874, č. j. 15308/LSR. Fond ZŠR, karton 17, signatura I/10/4. NA.

25 Přednesení během jednání zemské školní rady ze dne 7. 1. 1873, č. j. 17438/LSR. Fond ZŠR, karton 16, signatura I/10/4. NA.

26 Zpráva místodržitelského rady v Čáslavi prezidiu místodržitelství ze dne 28. 9.1874, č. j. 5194. Fond PM, karton 1091, signatura 2/2/1. NA. 
sám nechal zvolit. ${ }^{27}$ Právě podpora školství ze strany samosprávy nebyla vưbec samozřejmá, obce i okresy nesly poměrně nákladná finanční břemena, o to více stát dokázal ocenit - $\mathrm{i}$ ve formě patřičného císařského vyznamenání-vstřícný postoj jdoucí nad rámec zákonných povinností. Skutečnosti, že starosta (či kdokoliv jiný) byl aktivním členem okresní školní rady, místním školdozorcem, to, že obec ochotně přispívala na výstavbu místních školních budov a bez problému spolupracovala se státními úřady, patřily mezi důležité motivy, které se v návrzích na vyznamenání pravidelně objevovaly, a to nejen u všech starostů bez rozdílu jejich národnosti nebo politického přesvědčení. Cílem bylo jak ocenit zasloužilého místního činitele, tak i podpořit jeho postavení v lokální společnosti před jeho voliči a dokázat, že se tento proaktivní přístup a spolupráce s vládními úřady dlouhodobě vyplácí.

\section{Případ Louny}

Skutečně důsledná až násilná opozice proti školské reformě a těm, kdo ji zosobňovali, byla v Čechách nakonec výjimečná a podle zpráv, které docházely na české místodržitelství, lze soudit, že byla podmíněna souhrou řady lokálních faktorů. Za nejvážnější případ střetu mezi učiteli, občany, obcí a státem můžeme považovat lounské výtržnosti z let 1869 a 1870, jejichž motorem bylo dosazení místního římskokatolického děkana do funkce okresního školního inspektora pro okres Louny (Roedl, 2005, s. 222-225). Poté co byl původně jmenovaný Josef Valenta, profesor české reálky v Praze, přeložen do Slaného, navrhl okresní hejtman Ludwig von Malowetz právě děkana Františka Linharta. Spoléhal na jeho zkušenosti, kdy Linhart před svou instalací do úřadu místního faráře působil jako katecheta na hlavní škole, jenomže jeho obliba ve městě už v té době byla prakticky nulová. Původně populární kněz získal pověst hamižného preláta a jeho vztahy s obcí - která byla mimoto místním církevním patronem a do úřadu jej uvedla - i farníky se jen zhoršovaly (Kunc, 2009, s. 45-46). Pragmatický Linhart však v té

27 Zpráva okresního hejtmana v Německém Brodě prezidiu místodržitelství ze dne 28. 9. 1874, č. j. ad 5194. fond PM, karton 1091, signatura 2/2/1. NA. 
době prokázal hejtmanovi velkou službu. Při volbách do zemského sněmu v roce 1869 volil jako jeden z mála místních představitelů kandidáta vládní ústavověrné strany. Šlo o ryze demonstrativní volbu, po níž se děkan nadobro rozešel s místní českou většinou, hejtmanovi tím však dokázal svou loajalitu a provládní postoj navzdory svému kněžskému povolání. $^{28}$

Děkan Linhart se proto ještě v roce 1869 stal novým okresním školním inspektorem a tím i nadřízeným místních učitelů. Rok předtím se v Lounech otevřela nová hlavní škola a nižší reálka, na které obec přijala celou řadu poměrně mladých učitelů, přicházejících z Prahy či jiných center českého národního hnutí a radikálně vystupujících proti rakousko-uherskému vyrovnání a nerespektování českého státního práva. Právě tito učitelé - v čele s Antonínem Konstantinem Vitákem - stáli v popředí lounské učitelské opozice, která se $\mathrm{v}$ dalších měsících dostala do tvrdého střetu s konzervativně orientovaným děkanem. Zapojení učitelů do táborového hnutí, organizování veřejných demonstrací a otevřeně protivládní vystupování se neslučovalo s postavením učitele jako veřejného činitele a už vůbec neodpovídalo vládní snaze, aby právě učitelé byli nositelé liberálních myšlenek ve venkovském prostředí (Vostřel, 2013, s. 61-64). Tím, kdo měl příliš svobodomyslné učitele disciplinovat, byl v první řadě okresní školní inspektor. Tomu se v okresní školní radě podařilo prosadit, že byl v roce 1869 odvolán ředitel hlavní školy, suspendován byl A. K. Viták, další učitelé byli okresním hejtmanem potrestáni peněžitě. Učitel Karel Svoboda dokonce proti děkanovi založil petici, kterou adresoval na litoměřickou konzistoř, aby přikázala svému faráři vzdát se úřadu inspektora. Před Linhartovým domem se po několik nocí odehrávala tzv. kočičina, která kromě ztropení povyku skončila vytlučením oken děkanství (k průběhu událostí srov. Víták, 1902-1904).

Starosta nedokázal na vyhrocenou situaci ve městě reagovat, sám byl dalšími členy obecního výboru tlačen spíše do pasivní role, někteří

28 Zpráva okresního hejtmana v Lounech zemské školní radě v Čechách ze dne 27. 9. 1869, č. j. 1911. Fond ZŠR, karton 15, signatura I/10/4. NA. 
z radních a zastupitelů totiž otevřeně s učiteli sympatizovali a tajemník okresního zastupitelstva a radní Rudolf Vunš patřil dokonce mezi hlavní organizátory protivládních akcí. ${ }^{29}$ Aby opakované nepokoje nepřerostly v násilnosti, rozhodl se nakonec okresní hejtman Malowetz s podporou místodržitele Alexandra Kollera povolat do Loun eskadronu husarů, celkem 185 jezdcư, kteří měli na místo málo početné a pasivní městské stráže ve městě udržet klid a pořádek. Obec tato „pomoc“ stála několik tisíc zlatých na ubytování a stravování vojáků, hejtman mezitím nechal rozpustit místní občanské spolky. ${ }^{30}$

Lounská exekuce měla zřejmě posloužit jako odstrašující exemplum ukazující, kam až je státní moc ochotná zajít při prosazení zákonů a zároveň udržení klidu a pořádku. Faktem však zůstává, že hlavní př́íčinou eskalace napětí ve městě byly špatná volba okresního školního inspektora, ctižádostivý a horlivý okresní hejtman, radikální část učitelů a pasivní starosta. V této kombinaci nesehrál žádný ze jmenovaných aktérů roli prostředníka a mediátora, jejich činnost naopak situaci vyhrotila natolik, že po odvolání husarů z města musel odejít i okresní hejtman. Formálně byl povýšen a stal místodržitelským radou v Hradci Králové. Okresní školní inspektor Linhart zůstal na svém místě, ovšem ještě v roce 1872 město podniklo pokus se jej zbavit, když požádalo o vytvoření samostatného městského školního okresu omezeného jen na Louny. Zemská školní rada debatovala o jmenování nového inspektora, kterým se i přes námitky referenta stal opět neoblíbený František Linhart. ${ }^{31}$

\section{Závěr}

Reforma rakouského školství z konce 60. let 19. století představuje zásadní přelom v organizaci výuky a také v podobě státního dohledu

29 Zpráva okresního hejtmana v Lounech prezidiu místodržitelství ze dne 11. 1. 1870, č. j. 143. Signatura 6/5/31, karton 806, fond PM. NA.

30 Zpráva okresního hejtmana v Lounech prezidiu místodržitelství ze dne 23.1.1870, č. j. 342. Signatura 6/5/31, karton 806, fond PM. NA.

31 Přednesení během jednání zemské školní rady ze dne 28. 4. 1872, č. j. 15197/LSR. Fond ZŠR, karton 16, signatura I/10/4. NA. 
nad vzděláváním a výchovou občanů. Kontrola nad prací jednotlivých učitelů přešla do rukou kolektivních orgánů sestávajících ze státních úředníků, zástupců samosprávy, církve a samotných učitelů, výkonnými orgány školních rad na zemské i okresní úrovni se však stali státem jmenovaní inspektoři. Jednotlivá ustanovení zákona narazila nejen na různé politické, kulturní a sociální poměry v jednotlivých korunních zemích, ale také na personální a finanční limity státní správy. Do funkce okresních inspektorů, která byla zřízena jen jako vedlejší zaměstnání, se státu nedařilo sehnat vhodné kandidáty, což výrazně podvazovalo realizaci plánovaných změn v organizaci výuky a zlepšení stavu obecného školství. Dưraz na politické ohledy, loajalitu a správné smýšlení možného inspektora stejně jako finanční hledisko zvítězily nad odborně pedagogickou stránkou. Snaha státu ušetřit se projevila nejen na úkor samotných inspektorů, ale i ve vztahu k obecní samosprávě, kde se jen stěží hledaly obce ochotné přispívat na chod státní inspekce vlastními učiteli.

Problémy při zavádění nové struktury školské správy a četné improvizace, ke kterým se zemská školní rada, místodržitel i ministerstvo přitom museli uchýlit, nakonec vedly k poměrně rychlé novelizaci zemského zákona o školní dohlídce. V únoru 1873 císař sankcionoval nový zákon, který oproti předchozímu do značné míry omezil kompetence místní školní rady a tím i obecní samosprávy. ${ }^{32}$ Klíčovou roli v obecném školství měla napříště hrát okresní školní rada a její výkonná složka - okresní školní inspektor (Novotný, 2020, s. 232-237). Tento přesun z lokální úrovně na okresní byl důsledkem široké a dlouhodobé nevstřícnosti obecních i okresních výborů ke státní školské politice, respektive jejich autonomního a sebevědomého hájení vlastních zájmů. Dalším nepřímým důsledkem zůstalo i využití středoškolských učitelů a profesorů ve funkcích okresních inspektorů, které měly být původně rezervované v první řadě pro ty nejlepší učitele obecných či měštanských škol. Třebaže se již během prvních let po zavedení této

32 Srov. zákon č. 17 z. z. ze dne 24. 2.1873, jenž se týče místní a okresní dohlídky ke školám. Zemský zákonik království českého, 1873, částka VIII, s. 73-88. 
instituce opakovaně ozývaly hlasy, které kritizovaly absenci jakékoliv relevantní zkušenosti u gymnaziálních pedagogů a volaly po zavedení trvale systemizovaných míst obsazovaných nastálo, tato praxe zůstala zachována až do počátku 20. století. Okresní školní inspektor se stal sice běžnou postavou venkovského školství, svým charakterem však představoval spíše cizorodý prvek než nadřízeného, vzešlého organicky $\mathrm{z}$ řad místních učitelů.

\section{Literatura}

BALÍK, Stanislav, FASORA, Lukáš, HANUŠ, Jiří \& VLHA, Marek, 2015. Český antiklerikalismus. Zdroje, témata a podoba českého antiklerikalismu v letech 1848-1938. Praha: Argo. ISBN 978-80-257-1373-0.

BARTOŠOVÁ, Jana, ŠIMEK, Jan \& ŠUSTOVÁ, Magdaléna, 2019. Od školdozorce k inspektorovi. Historie školní inspekce, Praha: Česká školní inspekce ve spolupráci s Národním pedagogickým muzeem a knihovnou J. A. Komenského. ISBN 978-80-86935-46-1.

CIBULKA, Pavel, KLADIWA, Pavel, POKLUDOVÁ, Andrea, POPELKA, Petr \& ŘEPA, Milan, 2021. Čas změny. Moravský a slezský venkov od zrušení poddanství po Velkou válku. Praha: Masarykův ústav a Archiv AV ČR, v. v. i. ISBN 978-80-7599-225-3.

ENGELBRECHT, Helmut, 1982. Geschichte des österreichischen Bildungswesens. Erziehung und Unterricht auf dem Bodem Österreichs. Band 4: Von 1848 bis zum Ende der Monarchie. Wien: Österreichischer Bundesverlag. ISBN 3215051915.

HLAVAČKA, Milan, 2006. Zlatý věk české samosprávy. Samospráva a jeji vliv na hospodářský, sociální a intelektuální rozvoj Čech 1862-1913. Praha: Libri. ISBN 80-7277-297-X.

KLEČACKÝ, Martin a kol., 2020. Slovník představitelů politické správy v Čechách v letech 1849-1918. Praha: Masarykův ústav a Archiv AV ČR, Národní archiv. ISBN 978-80-88304-18-0; 978-80-7469-091-4.

KOLMER, Gustav, 1902. Parlament und Verfassung in Österreich. I. Band (1848-1869). Wien-Leipzig: Fromme.

KUNC, Ondřej, 2009. Lounské školstvív druhé polovině 19. století. Pardubice. Diplomová práce. Filozofická fakulta Univerzity Pardubice.

MACKOVÁ, Marie, 2011. Kde se vzal okresní školní inspektor? Lanškrounsko. Vlastivědný sbornik Městského muzea Lanškroun. Lanškroun: Městské muzeum v Lanškrouně. Roč. 9, s. 8-10. ISBN 978-80-260-0228-4.

NOVOTNÝ, Miroslav (ed.), 2020. Velké dějiny zemí Koruny české. Tematická řada Školstvi a vzdělanost. Praha: Paseka. ISBN 978-80-7432-985-2. 
ROEDL, Bohumír (ed.), 2005. Louny. Praha: NLN. ISBN 80-7106-662-1.

SRB, Adolf, 1899. Politické dějiny národa českého od roku 1861 až do nastoupení ministerstva Badenova r. 1895, Praha: F. Šimáček.

STRAKOSCH-GRASSMANN, Gustav, 1905. Geschichte des österreichischen Unterrichtswesens. Wien: Pichler's W.

ŠAFRÁNEK, Jan, 1918. Školy české. Obraz jejich vývoje a osudů. 2. díl. Praha: Matice česká.

TOBOLKA, Zdeněk V. (ed.), 1913. Česká politika. V. díl. Praha: Jan Laichter.

VOSTŘEL, Martin, 2013. Počátky lounského Sokola v kontextu bouřlivých let 1867 až 1871. In: Poohří 3. Ohře - spojnice lidí a osudů. Kadaň: Historie a současnost Poohří, o. s., s. 53-68. ISBN 978-80-905007-2-3.

VOŠAHLÍKOVÁ, Pavla, 2016. Rákoska v dílně lidskosti. Česká škola v 19. století očima účastníkủ. Praha: Academia. ISBN 978-80-200-2533-3.

\section{Nepublikované prameny}

Fond Zemská školní rada Praha, karton 1, signatura I/1/23. Národní archiv.

Fond Zemská školní rada Praha, kartony 15-17, signatura I/10/4. Národní archiv.

Fond Prezidium místodržitelství Praha, karton 806, signatura 6/5/31.

Národní archiv.

Fond Prezidium místodržitelství Praha, karton 1091, signatura 2/2/1. Národní archiv.

\section{Publikované prameny}

C. k. okresní inspektoři škol, 1869. Národní škola. Týdenik vychovatelský pro národní učitelstvo v Čechách, na Moravě, v Slezsku a na Slovensku. B. m., roč. 7, č. 44 (4.11.1869), s. 345-346.

JESSEN, Asmus Christian, 1870. Die Bezirksschulinspektoren. Freie pädagogische Blätter. Wien, roč. 4, č. 52 (24. 12. 1870), s. 801-803.

VÍTÁK, Antonín, 1902, 1904. Paměti starého učitele-vlastence persekucí postiženého. I., II. díl. Praha: Fr. A. Urbánek.

Zemský zákoník království českého, 1869, 1870, 1873. 